\section{Tumorßiology}

\title{
Editor-in-Chief's Note
}

\section{To Readers and Subscribers of Tumor Biology}

Tumor Biology, the journal of the International Society of Oncology and BioMarkers (ISOBM) has been published by Karger for several decades and has been a substantial part of ISOBM. During the last 10 years, I as Editor-inChief and Phil Rye as Managing Editor have appreciated the collaboration with Karger, recognizing their ambition to produce a good scientific journal. We owe them appreciation for this. During these decades the printing volume, size and impact factor have been growing and we would like to thank Karger for their efforts during these years. While we now choose to continue with another publisher, Springer, we wish Karger success in the future.

Umeå, 2 November 2009

Torgny Stigbrand, Editor-in-Chief 


\section{Tumorßiology}

Published online: November 20, 2009

\section{Publisher's Note}

\section{Dear Reader}

In accordance with the wishes of the International Society for Oncology and BioMarkers, we regret that this issue of Tumor Biology will be the last to be released by S. Karger AG, Basel, Switzerland. The journal will continue with Springer, with the first issue in 2010. The new publisher will contact you in good time with all necessary details concerning the future and availability of Tumor Biology.

Karger Publishers would like to express its appreciation to you as readers of and contributors to Tumor Biology and thank you for your loyalty and support during the past 23 years.

Basel, 2 November 2009

Karger Publishers

\section{Dear Subscriber to Tumor Biology}

We would like to inform you that as of volume 31 (2010), this journal will be published by Springer Science+Business Media (www.springer.com), and no longer by Karger Publishers.

Subscribers will receive their 2010 renewal notice/invoice from Springer's offices, either direct or through their agent.

Yours sincerely,

Springer Customer Service 